\title{
The Division of the Family Residence Acquired with a Mixture of Separate and Community Funds
}

The division of the family residence upon marital dissolution is a critical issue for many divorce litigants, im part because often much of a family's wealth is imvested in that single asset. ${ }^{1}$ In a community property state such as California, classification of the house as community property, or as the separate property of one of the spouses, can have a dramatic effect on the amount of property each spouse receives as part of the property settlement decree.

Under California law, property acquired before marriage, or by gift or inheritance, is classified as the separate property of the spouse receiving it. ${ }^{2}$ Durnig marriage, imcome from separate property also remains the separate property of the spouse owning the capital asset, ${ }^{3}$ as does any property bought by separate funds. ${ }^{4}$ All other property acquired during marriage, including income from employinent, is classified as community property. ${ }^{5}$

Thus, a residence bought before or during marriage solely with separate property, and with title taken solely in the purchasing spouse's name, remains the separate property of that spouse upon marital dissolution. A residence bought solely with community property is divided equally between the spouses, usually in the forn of an equal division of the proceeds from the sale of the house.

If a house is bought with a mixture of separate and community funds, however, its fate upon marital dissolution is usually less clear. At least two difficult questions regarding the proper application of community principles can arise. First, is the division of the house based on the source of the funds used to purchase the house, or is the division controlled by the form of ownership designated in the title deed? Second, if division is based on the source of the funds, which contributions to the purchase are considered, and low are they

1. E.g., 1 California Continuing Education of the Bar, California Marital DisSOlution PRACTICE $\$ \S 9.1-.24$ (1981).

2. CAL. Civ. CODE $\$ \S 5107-5108$ (West 1970).

3. Id.; see also Boyd v. Oser, 23 Cal. 2d 613, 621, 145 P.2d 312, 316-17 (1944).

4. CAL. Civ. CODE $\S \S 5107-5108$ (West 1970); see also Huber v. Huber, 27 Cal. 2d 784, 791, 167 P.2d 708, 712-13 (1946).

5. CAL. Civ. Code $§ 5110$ (West Supp. 1982). 
weighted in order to calculate the interests of the spouses in the residence?

Under the California Supreme Court's recent decisions in In re Marriage of Lucas ${ }^{6}$ and In re Marriage of Moore ${ }^{7}$, the form of title determines the division of the residence unless there is an agreement between the spouses to the contrary. If there is an agreement to the contrary, the source of funds is used to allocate the imterests in the residence. Under the Lucas/Moore source of funds method, only "contributions to equity" are taken imto account, defined by the court to include the down payment, monthly principal payments, and unpaid loan balance attributable to each party, but excluding any amounts paid for interest, insurance, or property taxes.

This Comment analyzes the rules for the division of the family residence established by Lucas and Moore. Part I summarizes the Lucas and Moore decisions. Part II critiques the Lucas "gift presumption" that a separate property contribution toward the purchase price of a house purchased during marriage is a gift to the community, unless an agreement between the spouses to the contrary can be proven. Part III examines different proposed unetlods for dividing the family residence upon marital dissolution considered in Lucas and Moore. Part III then criticizes the Lucas/Moore fornula, and proposes a modification which mitigates the unmodified approacli's harsh results.

I

\section{The LuCAS AND MOORE CASES}

\section{A. Lucas and the Gift Presumption Issue}

In re Marriage of Lucas ${ }^{8}$ mvolved Brenda and Gerald Lucas, who were married in March 1964. Four years later they bought a house, using Brenda's separate funds to make the down payinent and jointly assuming a loan for the balance of the purchase price. They took title to the louse as "Husband and Wife as Joint Tenants." Aside from about $\$ 3,000$ worth of improvements made to the house from Brenda's separate funds, all of the expenses relating to the house were paid out of community funds. ${ }^{9}$ Brenda and Gerald separated in 1976, and were subsequently divorced.

At the trial fixing the status of the couple's assets as community or separate property, the court treated the down payinent by Brenda as her separate property contribution to the purchase of the house. ${ }^{10}$ It
6. 27 Cal. 3d 808, 614 P.2d 285, 166 Cal. Rptr. 853 (1980) (Manuel, J.) (7-0 decision).
7. 28 Cal. 3d 366, 618 P.2d 208, 168 Cal. Rptr. 662 (1980) (Manuel, J.) (7-0 decision).
8. 27 Cal. 3d 808, 614 P.2d 285, 166 Cal. Rptr. 853 (1980).
9. Id. at 811,614 P.2d at $287,166 \mathrm{Cal}$. Rptr. at 855 .
10. Id. at 812,614 P.2d at $287,166 \mathrm{Cal}$. Rptr. at 855 . 
treated the loan principal payments as the community property contribution to the purchase of the house. The court first returned each party's contributions to the purchase. It then divided the appreciation by summing the down payment and principal payments, calculating the percentage of this sum attributable to Brenda's separate property share (the down payment) and to the community share (the principal payments), and dividing the house appreciation based on these percentages. ${ }^{11}$

In a unanimous decision, the California Supreme Court reversed the trial court, holding that to maimtain the separate property character of the down payment, Brenda had to prove the existence of an "understanding" or an "agreement" to that effect. ${ }^{12}$ The court based its holdimg on its imterpretation of the "family residence" presumption in section 5110 of the California Civil Code, which states that a residence acquired during marriage by spouses as joint tenants is presumed to be commumity property upon dissolution of the marriage. ${ }^{13}$ Lucas held that the family residence presumption could not be overcome by tracing the down payment to a separate property source, and could only be overcome by an agreement that a separate property down payment would retaim its separate property character. ${ }^{14}$ The effect of this holding was that Brenda's down payment was treated as a gift to the community.

The court supported its holding that only an agreement could overcome the family residence presumption by reasoning that

[t]he presumption arising from the form of title [here, a deed to the Lucas' as joint tenants] is to be distinguished from the general presumption set forth in Civil Code section 5110 that property acquired during marriage is community property. It is the affirmative act of

11. See Appellant's Opening Brief at 5, Lucas.

12. $27 \mathrm{Cal}$. 3d at 816,614 P.2d at $289,166 \mathrm{Cal}$. Rptr. at 858.

13. Section 5110 of the Civil Code provides, in relevant part:

[Except for property defined to be separate,] all real property situated in this state and all personal property wherever situated acquired during the inarriage by a inarried person while domiciled in this state . . . is community property; but whenever any real or personal property, or imterest therein or encunnbrance thereon, is acquired prior to January 1,1975 , by a married woman by an instrument in writing, the presunuption is that the same is her separate property, and if so acquired by such inarried woman and any other person the presumption is that she takes the part acquired by her, as tenant in common, unless a different intention is expressed in the instrument; except, that when any of such property is acquired by husband and wife by an instrument in which they are described as husband and wife, unless a different intention is expressed in the instruinent, the presumption is that such property is the community property of the husband and wife. When a single-family residence of a husband and wife is acquired by thein during marriage as joint tenants, for the purpose of division of such property upon dissolution of marriage or legal separation only, the presuinption is that such single-fanily residence is the community property of the husband and wife.

Cal. Clv. Code $\S 5110$ (West Supp. 1982).

14. $27 \mathrm{Cal}$. 3d at 814, 614 P.2d at 288, 166 Cal. Rptr. at 856-57. 
specifying a form of ownership in the conveyance of title that removes such property from the more general presumption. It is because of this express designation of ownership that a greater showing is necessary to overcome the presumption arising therefrom than is necessary to overcome the more general presumption that property acquired during marriage is community property. In the latter situation, where there is no indication of ownership interests as between spouses, the general presumption of community property may be overcome simply by tracing the source of funds used to acquire the property to separate property. ${ }^{15}$

Since the Lucas trial court had not decided whether an agreement establishing the separate property character of the down payinent existed, the supreme court remanded the case for resolution of that issue. To guide the lower court in the event it found an agreement, the supreine court outlined the formula to be used for calculating the community and separate interests in a residence upon a marital dissolution. ${ }^{16}$ The chief distinguishing characteristic of the court's formula is that it treated the loan proceeds as one of the assets to be counted in determining the separate and community property shares in the house. The separate or community character of the loan depended upon whether the loan was taken out before or during the marriage. Because the loan in this case was obtained durmg marriage, the loan proceeds were classified as community funds. ${ }^{17}$

\section{B. Moore and the Division Scheme}

The Moore court clarified the Lucas scheme for division of the house by elaborating on the method by which the loan proceeds were to be taken into account. In re Marriage of Moore ${ }^{18}$ involved Lydie and David Moore, who narried in 1966 and lived together until their separation in 1977. In contrast to Lucas, the spouse in Moore bought the house before her marriage. Lydie Moore used her separate property for the down payinent, secured a loan in her own name for the balance of the purchase price, and took title to the house as "Lydie S. Doak, a single woman." As in Lucas, all expenses relating to the property incurred during inarriage were paid front community sources. At trial, the court concluded that the house was mainly Lydie's separate property, but that the community had an niterest in it by virtue of the loan

15. Id. at $814-15,614$ P.2d at 288,166 Cal. Rptr. at 857 (citations omitted).

16. Id. at $816 \mathrm{n} .3,614 \mathrm{P} .2 \mathrm{~d}$ at $290 \mathrm{n} .3,166 \mathrm{Cal}$. Rptr. at $858 \mathrm{n} .3$. The formula originated in In re Marriage of Aufmuth, 89 Cal. App. 3d 446, 456-57, 152 Cal. Rptr. 668, 674-75 (1st Dist. 1979).

17. Lucas, 27 Cal. $3 d$ at $816-17$ \& n.3, 614 P.2d at $290 \&$ n.3, 166 Cal. Rptr. at 858 \& n.3.

18. 28 Cal. 3d 366, 618 P.2d 208, 168 Cal. Rptr. 662 (1980). 
principal payments made from community funds. ${ }^{19}$

To calculate the community and separate interests in the property, the trial court in Moore used the same formula as did the trial court in Lucas. ${ }^{20}$ David appealed on the grounds that the trial court should have included taxes, interest, and insurance payments in the calculation, rather than only payinents attributable to primcipal. ${ }^{21}$

On appeal, the California Supreine Court disagreed with the trial court's division of the property, but did not accept David's arguinent that non-principal items should be included in the calculation. The court held ${ }^{22}$ that the calculation of the house purchase contributions should be based solely on the reduction in principal made by community and separate funds. The court reasoned that "[t]he value of real property is generally represented by the owner's equity in it, and the equity value does not include finance charges or other expenses incurred to inaintain the investinent." 23 The court added that if payments of taxes, insurance, and interest were considered in calculating the community's contribution, then "fairness would also require that the community be charged for its use of the property."24

The court then applied the Lucas formula, treating Brenda's down payment and the loan proceeds as her separate property contributions

19. Id. at 370,618 P.2d at 209, 168 Cal. Rptr. at 663 . Lydie did not contest the community's asserted interest in the property. See id. at 271 \& n.1, 618 P.2d at 209-10 \& n.1, 168 Cal. Rptr. at 663-64 \& n.1. There has been soine specnlation as to why this point was uncontested, and how the authority of Moore as precedent on that issue is affeeted by it. See, e.g., 1980 CAL. FAM. L. REP. 1458, 1460. Since the Lucas case was decided long after the Moore trial, Lydie's attorneys probably could not have anticipated that the suprene conrt might have been willing to give her the whole house. Alternatively, there may have been strong evidence of an interspousal agreeinent which appeared futile to contest.

As a result of Lydie's failure to contest the community's asserted interest in the property, the Moore decision can be interpreted in at least two different ways. Under one interpretation, Moore could be read as the converse of Lucas, implying that if Lydie had contested the issue, she wonld have received a 100 percent separate property interest in the house unless David could prove an inconsistent interspousal agreement. Because Lydie did not contest the community interest, the issue was not before the supreme court. Under another interpretation, the community would have been awarded an interest in the property irrespective of whether Lydie had contested the issue. The trial court did conclude that "the community had an interest in [the residence] by virtue of the community property payments made during the parties' marriage." $28 \mathrm{Cal} .3 \mathrm{~d}$ at $370,618 \mathrm{P} .2 \mathrm{~d}$ at 209, $168 \mathrm{Cal}$. Rptr. at 663 (emphasis added). The supreine court did not specificially reverse the trial court's conclusion, stating "[t]he judgment is affirmed in all other respects." $I d$. at 375,618 P.2d at 212, 168 Cal. Rptr. at 666.

20. Compare Appellant's Opening Brief at 5, Lucas with Petition for Hearing at 3-4, Moore.

21. 28 Cal. $3 d$ at 372,618 P.2d at 210, 168 Cal. Rptr. at 664-65.

22. Although the supreme court ultimately concluded that the trial court's judgment was the product of harmless error, $i d$. at 374,618 P.2d at 212,168 Cal. Rptr. at 666 , its method of dividing the house is not dicturn. The supreme court had to decide the proper method of determining the separate and community interests before it could determine which party benefited by the error. Thus, the method of division is part of the holding.

23. Id. at $372,618 \mathrm{P} .2 \mathrm{~d}$ at $211,168 \mathrm{Cal}$. Rptr. at 665 .

24. Id. at $372-73,618$ P.2d at 211,168 Cal. Rptr. at 665 . 
because both were contributed before marriage. ${ }^{25}$ The community contribution was therefore limited to the reduction in principal attributable to loan payments made during marriage. Consequently, the amount of property appreciation allocable to the community was minimal. ${ }^{26}$

\section{An Example Using the Lucas/Moore Principles}

The principles announced in Lucas and Moore lead to very different results under the facts of the two cases. The presumption that a down payinent made from separate property during marriage is a gift, while a down payment before marriage is not a gift, means that the separate and community property shares in the house are greatly affected by whether the house is purchased before or during the marriage. The classification of the mortgage loan as a separate or community contribution, depending upon whether it is made before or during the marriage, leads to the same divergent results. Thus, under Lucas and Moore, a house bought the day before a marriage will have a significantly smaller community property share than a house bought the day after a marriage.

The following example can be used to illustrate the effect of the Lucas/Moore principles. A husband and wife purchase a house for $\$ 100,000$, taking title to the property as joint tenants. The wife pays the $\$ 20,000$ down payment out of her separate property, and the couple takes out an $\$ 80,000$ loan secured by a deed of trust. Some years later, after the loan payments have been made out of community funds, the loan balance ${ }^{27}$ has been paid down to $\$ 78,000$, but the property's value is now $\$ 180,000$, representing appreciation ${ }^{28}$ of $\$ 80,000$ over the purchase price. The equity ${ }^{29}$ in the house is thus $\$ 102,000$ - the $\$ 180,000$ property value less the outstanding loan balance of $\$ 78,000$. At this point, the inarriage is terminated.

25. Id. at 373,618 P.2d at 211,168 Cal. Rptr. at 665 .

26. In the Moore case, the community's share of the total equity in the house amounted to about 13 percent. In the Lucas case, that share was about 63 percent. The disparity between the figures is remarkable, for although none of the monthly mortgage payments in Lucas were made out of separate funds, only seven paynents were made from separate funds in Moore. Moore, 28 Cal. 3d at 370, 618 P.2d at 209, 168 Cal. Rptr. at 663; Lucas, 27 Cal. 3d at 812, 614 P.2d at 287, 166 Cal. Rptr. at 855 .

27. The loan balance is the outstanding principle balance on the loan. Commonly, loans made by financial institutions for house purchases require nonthly payinents over a thirty year term. If the loans are fully amortizing with level monthly payments, the principal portion of the early nonthly payments is very small and the interest portion is very high, but the principal portion of the monthly payments increases consistently over the loan terin.

28. "Appreciation" is the increase, if any, between the narket value of the house at purchase and the market value at sale.

29. "Equity" is the market value of the house less the outstanding principal balance on the loan. Thus, the equity is typically consposed of the down payment, the total principal payments on the loan, and the appreciation. 
Applying the Lucas/Moore principles to the example, the entire house will be presuined to be community property because the down payment and loan were made during marriage and the principal payments came from community funds. However, if the wife can establish an agreement that her down payment was to retain its separate property character, the down payment will be counted as the wife's separate property interest im the house. Since her down payment contribution constituted twenty percent of the purchase price, the $\$ 20,000$ down payment, as well as twenty percent of the $\$ 80,000$ appreciation in property value $(\$ 16,000)$, will be allocable to her separate property. The remaining $\$ 66,000$ of the $\$ 102,000$ equity is allocable to the principal payments and loan balance and will be considered community property.

If instead the house purchase in the example had been made by the wife just prior to the marriage, very different consequences would ensue under Lucas and Moore. Since the wife would have made the down payment before marriage, there would be no presumption that the down payment was a gift to the community. Furthermore, because the loan would have been made to the wife before inarriage, the loan balance would be counted toward the wife's separate property share of the appreciation in the house, rather than toward the community's share. Thus, because the only community contribution to the purchase price of the house would have been the $\$ 2,000$ reduction in the loan balance froin the principal payinents on the loan, the commumity would have only a two percent interest in the house. In other words, two percent of the $\$ 80,000$ appreciation in the house, or $\$ 1,600$, would be allocable to community property, as would the $\$ 2,000$ principal reduction. The remaining $\$ 98,400$ of equity would be the wife's separate property interest.

Thus, the Lucas/Moore formula creates great differences in divisions of residences which depend in part upon whether the loan is taken out and the down payment is inade before or during inarriage. If the loan is taken out before marriage, the loan balance is treated entirely as a separate property contribution, while if the loan is taken out during marriage, it is treated entirely as a community property contribution. Moreover, a down payment from separate property before marriage is treated as a separate property contribution while a down payment from separate property during marriage, where the couple takes title as joint tenants, is presunied to be community property. The Lucas and Moore primciples leading to these classifications are critiqued in the next two Parts of this Comment. 


\section{II \\ The Lucas Gift Presumption}

The Lucas court heId that Brenda Lucas was presumed to have intended a gift to the community when she made the down payment on the family residence. ${ }^{30}$ This presumption was not overcome even though the down payment could be traced to her own funds. Nor was it relevant that the trial court believed her testimony that she did not intend to make a gift; ${ }^{31}$ the family residence presumption could only be overcoine by proof of an agreement to the contrary. ${ }^{32}$ As a result, unless Brenda could prove the existence of such an agreenent, the house would be classified as wholly community property. ${ }^{33}$

This Part argues that Lucas was incorrect in construmg the family residence presumption of section 5110 as requiring a separate property down payinent during marriage to be presumptively classified as community property. Section A reviews the relevant background of Cahfornia property law, including the history of the four presumptions contained in section 5110. Section B argues that the Lucas court's decision was incorrect in light of proper statutory interpretation, legislative history, and policy.

\section{A. Legal Background}

This Section will briefly review the history of the community property system as adopted in California. In so doing, it will discuss the reasons for the legislative adoption of the four presumptions in section 5110 and for the judicial presuniption of title for property deeded to joint tenants.

Under the original civil law system as practiced in California before statehood and as practiced in other jurisdictions, property in the possession of a married person was classifled as either separate or community. This classification was accomplished by tracing the acquisition of the property to either a separate or a community source. ${ }^{34}$ For example, a piece of property acquired by a spouse by gift or purchased before inarriage was classified as separate. On the other hand, property acquired during marriage by the labors of one of the spouses was classified as community. Furtherniore, property acquired by means of separate or community funds took on the status of those funds. Under the civil law, this classiffcation of property by the source of purchase funds

30. Lucas, 27 Cal. 3d at 813, 614 P.2d at 287, 166 Cal. Rptr. at 856.

31. Id. at 815,614 P.2d at $288,166 \mathrm{Cal}$. Rptr. at 857 .

32. Id. at 813,614 P.2d at 287,166 Cal. Rptr. at 856 .

33. Id. at 815,614 P.2d at 288,166 Cal. Rptr. at 857 .

34. The precise distinction is between "lucrative title" and "onerous title." See W. DE Funiak \& M. Vaughn, Principles of Community Property \& 62 (2d ed. 1971). 
generally could not be altered by post-marital agreements of the spouses. $^{35}$ Thus, a deed purporting to be a transfer of property from one spouse to another would not raise a presumption that the receiving spouse owned the property. ${ }^{36}$

California's first constitution directed the legislature to adopt a community property system in California.$^{37}$ Accordingly, California's community property system was implemented by legislation in 1850 . The foundation of this systein was the "general community property" presumption, which provides that property acquired during marriage is community property. ${ }^{38}$ This presumption is one of the four presumptions now found im section 5110 of the Civil Code.

California did not adopt the community property system exactly as it was practiced in civil law jurisdictions. Most significantly, the common law was adopted as the primary rule of decision in California, ${ }^{39}$ and common law property principles exerted considerable influence on early California community property doctrine. Common law estates $\mathrm{m}$ land coexist with the community property system in California, producing a mixed common law/community property system with two separate, often conflicting strands of doctrine. This mixed systein applies the common law rule that it is permissible to alter by contract the rights of the spouses in a particular property, rather than the civil

35. For imstance, under Spanish law, gifts from one spouse to the other were revocable until death. Loewy, The Spanish Community of Acquests and Gains and its Adoption and Modification by the State of California, 1 CALIF. L. Rev. 32, 41 \& n.44 (1912); R. Ballinger, A Treatise on The

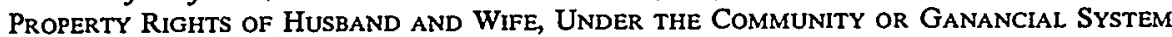
$\S 58$ (1895); see Fuller v. Ferguson, 26 Cal. 546, 573-75 (1864).

36. See, e.g., Meyer v. Kinzer, 12 Cal. 247, 253 (1859) (Field, J.) ("The title being in her name does not even raise a presumption in her favor.") (quoting with approval Smalley v. Lawrence, 9 Rob. 210,214 (La. 1844)); R. BALLINGER, supra note $35, \S \S 38$ \& n.4, 170 \& n.4. But cf. id. $\$ 171$ (deed from husband or third person to wife presumed gift). See generally De Funiak \& Vaughn, Why Community Property is so Misunderstood-Knowing its Origin is the Key, 1 CommUNITY PROP. J. 97 (1974).

37. Cal. Const. of 1849, art. XI, $\$ 14$ (current version at CAL. Const. art. I, \$21). See Loewy, supra note 35, at 32; see also McMurray, The Beginnings of the Community Property System in California and the Adoption of the Common Law, 3 CAlIF. L. REv. 359 (1915); Prager, The Persistence of Separate Property Concepts in California's Community Property System, 1849.1975, 24 U.C.L.A. L. REv. 1 (1976).

38. Act of Apr. 17, 1850, ch. 103, 1850 Cal. Stat. 254 (current version at CAL. Civ. Code $\S 5110$ (West Supp. 1982)). This part of the statute is treated as a presumption even though it is in the form of a statement. If the property can be shown to have been acquired before marriage, or otherwise in the manner specified in CAL. CIV. CODE $\$ \S 5107-5108$ (West 1970) (defining separate property of husband and wife), it is not classified as community property. In the absence of such evidence, the property is assumed to be community. See, e.g., In re Marriage of Cademartori, 119 Cal. App. 3d 970, 972, 174 Cal. Rptr. 292, 293 (1st Dist. 1981); but see Fidehty \& Cas. Co. v. Mahoney, 71 Cal. App. 2d 65, 161 P.2d 944 (1945) (two-month marriage; no presumption property in possession of parties is community).

39. Act of Apr. 13,1850, ch. $95, \S 1,1850$ Cal. Stat. 219 (current version at CAL. CIV. CodE $\S 22.2$ (West 1954)). 
law rule that the status of such property cannot be altered by agreement. ${ }^{40}$

Common law principles also mfluenced the allocation of management power over property between husband and wife. The $1850 \mathrm{com}$ munity property legislation gave the husband power of management and control over not only the community property, but also over the wife's separate property. ${ }^{41}$ This vesting of management and control in the husband produced a marital property law coinparable to that resultimg from Married Wonien's Property Acts found in common law states $^{42}$-it reduced the wife's interest in the comnunity property to a "mere expectancy." 43

By the time of the adoption of the 1872 Civil Code, it was recognized that the near elimination of the wife's rights in the community property was inconsistent with the original intent behind adopting the community property system. As a result, certain counterbalancing rights were created for the wife. ${ }^{44}$ With the the 1872 Code, the wife regamed full inanagement over her separate property. ${ }^{45}$

In 1889, the legislature enacted the "married wonian" presumption, ${ }^{46}$ which provides that title to property acquired by a married woman via a written instrument is presumed to be her separate property, and, if the property is held with another person, that the wife's interest be held as a tenant in common. This is the second presuinption now found in section 5110 of the Civil Code. It was apparently based on the rationale that because community property was under the management and control of the husband, and thus a married woinan could only control her own property, such property had to be held clearly in her name so third parties could rely on her exercise of management power over it. $^{47}$

The married woman presuinption had undesired side effects, however. Because the married woman presumption applied to "any real or personal property, or any interest therein" 48 acquired by a married woman by an instrument in writing, it resulted in women receiving a disproportionately large share of property conveyed, without designation of the form of title, to a husband and wife. Courts held that property so

40. CAL. CIv. CODE $\S 5103$ (West 1970) (originally enacted in 1872).

41. Act of Apr. 17, 1850, ch. 103, \&6, 1850 Cal. Stat. 254, 254.

42. See Prager, supra note 37 , at $34,39-46$.

43. Van Maren v. Johnson, 15 Cal. 308, 311 (1860) (Field, J.).

44. See generally Prager, supra note 37, at 39-46.

45. See CAL. CIv. Code $\$ 5107$ (West 1970).

46. Act of Mar. 19, 1889, ch. 215, § 1, 1889 Cal. Stat. 328, 328 (current version at CAL. CIV. CODE $\$ 5110$ (West Supp. 1982)).

47. See Prager, supra note 37, at 44.

48. Cal. Civ. Code $\S 5110$ (West Supp. 1982). 
conveyed was presuuned to be held as tenants in common, ${ }^{49}$ with half as the wife's separate property and half, although held in the husband's name, as community property. ${ }^{\text {so }}$ Thus, the effect of the married woinan presumption was that the woman, upon inarital dissolution, received three-fourths of all property conveyed to the husband and wife during marriage-half of the property as her separate share and half of the remaiming half as her share of the community property. This was contrary to the underlying purpose of the community property systen that the husband and wife receive equal shares of property acquired by the community. ${ }^{51}$

This unequal allocation was altered by the addition in 1935 of what is now the third presuinption of section 5110, the "husband and wife" presumption: property conveyed to a husband and wife is presumed to be the community property of the couple. ${ }^{52}$ The husband and wife presumption overrode the courts' interpretation of the nrarried woman presumption, and restored the principle that niarital property is divided equally between the spouses.

By their terins, neither the married woman presuinption nor the husband and wife presumption apply if a different intention is expressed in the deed. ${ }^{53}$ If the deed designates a common law estate, then common law property rules will be applied instead of community property rules. For instance, in Siberell v. Siberell, ${ }^{54}$ decided before the enactment of the husband and wife presumption, the court held that the words "as joimt tenants" sufficed to remove a conveyance front the married woman presumption. Application of the presuniption would have resulted in the spouses holding the property unequally, a result incompatible with the definition of joint tenancy. ${ }^{55}$ The Siberell court held that in such cases there was a presumption that the spouses had agreed

49. See supra text accompanying note 46. The married woman presumption applies "unless a different intention is expressed in the instruinent." See supra note 13.

50. Dunn v. Mullan, 211 Cal. 583, 587-88, 296 P. 604, 606 (1931).

51. Compare Prager, Sharing Principles and the Future of Marital Property Law, 25 U.C.L.A. L. REv. 1 (1977) with Glendon, Is There a Future for Separate Property, 8 FAM. L.Q. 315, 31 15-16, 326 (1974). Sce generally Bruch, The Definition and Division of Marital Property in California: Toward Parity and Simplicity, 33 HAsTings L.J. 769 (1982).

52. Act of July 16, 1935, ch. 707, § 1, 1935 Cal. Stat. 1912, 1912.

53. See supra note 13.

54. 214 Cal. 767, 7 P.2d 1003 (1932), discussed in Note, Community Property: Status of Propcrty Conveyed ro Husband and Wife as Co-Grantees, 20 CALIF. L. Rev. 546 (1932).

55. The joint tenancy deed is important to the result in Siberell. Unequal co-ownership would not be inconsistent with holding the property as tenants in common. If no form of title is specified, tenancy in common is presumed between a woman and another person (if the husband and wife presumption does not apply). See supra notes 13, 49. This accounts for the difference between Siberell and Dunn v. Mullan. In Dunn v. Mullan, there was no designation of the form of ownership and tenancy in common was presumed, so the fact that the interests of the lusband and wife were unequal did not pose any doctrinal problems. See supra note 50 and accompanying text. 
to hold the property in the manner indicated in the title document. ${ }^{56}$ Overturning this presumption arising from the deed required proof of an agreement to the contrary. ${ }^{57}$

One consequence of Siberell was that a significant amount of inarital property was governed by common law rules rather than by community property rules. After Siberell, California divorce courts refused to hold tracing of funds to community sources sufficient to overcome the presumption of separate ownership in joint tenancy deeds. ${ }^{58}$ This line of cases put the divorce courts in a peculiar position. They had jurisdiction over community property and power to decide whether property was community or separate. Once they decided property was separate, however, they lost subject inatter jurisdiction over it and thereby lost the power to divide it between the parties. ${ }^{59}$ In particular, because California couples often held title in the common law estate of joint tenancy, divorce courts could not award the family residence to the spouse with custody of the children for the children's support. ${ }^{60}$

The California legislature recognized this problem, and in 1965, in an atteinpt to give divorce courts power of disposition over a joint tenancy residence, it enacted the "family residence" presumption, the fourth presunption in section 5110 . This is the presumption whose construction was at issue in Lucas. The family residence presumption provides that a residence acquired during marriage and held in joint tenancy by the spouses is presuined to be community property. ${ }^{61}$

The last amendment to section 5110 occurred in 1973. In that year, the legislature repealed the inarried woman presumption for transfers occurring after 1975,62 and also amended the Civil Code to provide for the co-management of coinmunity property ${ }^{63}$

\section{B. Critique of the Lucas Holding}

In In re Marriage of Lucas, the California Supreme Court held

56. 214 Cal. at 773,7 P.2d at 1005 .

57. See, e.g., Gudelj v. Gudelj, 41 Cal. 2d 202, 212, 259 P.2d 656, 662 (1953); Socol v. King, 36 Cal. 2d 342, 345, 223 P.2d 627, 629-30 (1950). Merely tracing the funds to sources other than the titled owner would not suffice to overturn a presumption of an agreement, because it is not imconsistent with such an agreement.

58. See, e.g., Gudelj, 41 Cal. 2d at 212, 259 P.2d at 662.

59. Fox v. Fox, 18 Cal. 2d 645, 646, 117 P.2d 325, 326 (1941); 7 B. WITKIN, SUMMARY OF California Law Community Property $\$ \S 92,98$ (8th ed. 1974); see CAL. Civ. CoDE $\$ \S 4800,4813$, 5102 (West Supp. 1982).

60. See, e.g., Final Report of the Assembly Interim Comm. on Judiciary Relating to Domestic Relations, vol. 23, no. 6, pt. 5, at 117, 122-23, reprinted in 2 App. Cal. Assem. J. (1965) [hereinafter cited as Domestic Relations Report].

61. Act of July 17, 1965, ch. 1710, \& 1, 1965 Cal. Stat. 3843, 3843-44.

62. Id. $\& 5,1973$ Cal. Stat. at 1898 .

63. Act of Oct. 1, 1973, ch. $987, \S \S 14-15,1973$ Cal. Stat. 1897, 1901-02. The effective date of this amendment was January 1, 1975. Id. $\$ 20,1973$ Cal. Stat. at 1905. 
that the legislature had intended to incorporate into the family residence presumption all of the requirements for overcoming the common law presumption of title arisimg from the deed, ${ }^{64}$ even though the family residence presumption presumed that a title designated as the common law estate of joint tenancy was imstead community property. Given the language and purpose of the presumptions in section 5110 , the Lucas holding regarding the showing needed to overcome the family residence presumption is not well supported. Nothing im the text of section 5110 indicates that the family residence presumption is any more conclusive than the other section 5110 presumptions, all of which may be overcome by tracing the source of the purchase funds. Moreover, the legislative history of the statute suggests that the legislature intended that the family residence presumption could be overcome by tracing. Finally, a rule that property can be presumed to be community property even though tracing clearly demonstrates otherwise-in effect presuming a gift to the community - is no longer justified on policy grounds.

\section{Statutory Language and History}

In hight of the circumstances surrounding its enactinent, the wordmg of the family residence presumption in section 5110 provides several imdications that the presumption was intended to be rebuttable by tracing. First, the other presumptions in section 5110-the general commumity property, ${ }^{65}$ married woman, ${ }^{66}$ and husband and wife presumptions ${ }^{67}$ - have been held to be overcome by tracing. Generally,

64. "There is no indication that the Legislature intended in any way to change the rules regarding the strength and type of evidence necessary to overcoine the presumption arising froin the form of title." Lucas, 27 Cal. 3d at 814, 614 P.2d at 288, 166 Cal. Rptr. at 857.

65. In re Marriage of Mix, 14 Cal. 3d 604, $611-12,536$ P.2d 479, 484, 122 Cal. Rptr. 79, 84 (1975); See v. See, 64 Cal. 2d 778, 783, 415 P.2d 776, 780, 51 Cal. Rptr. 888, 892 (1966). See generally 32 CAL. JUR. 3D Family Law $\$ 435$ \& n.98 (1977); 7 B. WITKIN, supra note 59, Community Property \$ 33.

66. See In re Marriage of Rives, 130 Cal. App. 3d 138, 162-63, 181 Cal. Rptr. 572, 586 (2d Dist. 1982); see also Thompson v. Thompson, 172 Cal. 491, 494, 157 P. 595, 596 (1916); Attebury v. Wayland, 73 Cal. App. 2d 1, 5, 165 P.2d 524, 526 (1st Dist. 1946). But cf. Whittaker v. Whittaker, 137 Cal. App. 396, 399, 30 P.2d 538, 539 (3d Dist. 1934) (tracing alone is insufficient to support finding of gift unless coinbined with credible evidence of intent not to inake a gift; intent need not have been disclosed).

67. Cardew v. Cardew, 192 Cal. App. 2d 502, 515, 13 Cal. Rptr. 620, 627 (1st Dist. 1961); 7 B. Witkin, supra note 59, Community Property $\S 46$; cf. In re Marriage of Wall, 30 Cal. App. 3d 1042, 1048, 106 Cal. Rptr. 690, 694 (2d Dist. 1973). But of. Williams v. Williams, 178 Cal. App. 2d 522, 526-27, 3 Cal. Rptr. 59, 63 (3d Dist. 1960).

In Cardew, the court stated: "We also think the effect of the [husband and wife] exception is to establish but one presumption-that the property is community-the same presumption that attaches to all property acquired during the marriage under the first clause of section 164 [now 5110]." 192 Cal. App. 2d at 515, 13 Cal. Rptr. at 627. However, the, court had other grounds arguably sufficient to sustain the trial court's finding of community property; for example, the 
like terms in a statute are presumed to have identical meanings unless the legislature intends otherwise. ${ }^{68}$ Therefore, the family residence presumption should be overcome by tracing unless there is a good reason not to do so. ${ }^{69}$

Second, the family residence presumption provides that where a residence is held in joint tenancy, "the presumption is that such single family residence is the community property of the husband and wife." 70 Because the family residence presumption concerns property whose title was designated as joint tenancy on the deed, the Lucas court held that the presumption was governed by the saine evidentiary standard that governed the title presumption of joint tenancy arising from the common law deed. Prior cases have consistently held tracing insufficient to overcome the presumption of title arising from a joimt tenancy deed, ${ }^{71}$ on the theory that proof of unequal ownership was inconsistent with the joint tenancy form of ownership. ${ }^{72}$ These cases have specifically rejected the possibility that the presumption could be overcome by a hidden intent of the grantor ${ }^{73}$ (e.g., an intent that a down payment retain its separate property character), a factor sometimes mentioned in the cases dealing with the other section 5110 presumptions. ${ }^{74}$ Thus, the Lucas court held that the family residence presumption could not be overcome by tracing.

Lucas incorrectly looked to the general presumption relating to property deeded in joint tenancy in determining what evidence can overcome the family residence presumption, however, rather than the specific section 5110 presumptions relating to property acquired during

form of title was suggested by the title company, and the purchase was made while the husband, a merchant marine captain, was away on a voyage. 192 Cal. App. $2 \mathrm{~d}$ at 513, 13 Cal. Rptr. at 626.

68. 2A C.D. SAND, SUTHERLand Statutory Construction $\$ 51.02 \&$ n.10 (4th ed. 1973 \& Supp. 1982) (citing People v. Hill, 103 Cal. App. 3d 525, 532-35, 163 Cal. Rptr. 99, 103-06 (1st Dist. 1980)).

69. One such "good reason" may be that the fourth presumption was addressed to a different sort of problem than the first three, namely the concern that the house be available for the support of the minor children as opposed to the balance of spousal power. Arguably, tracing is contrary to the purpose of the fourth presumption, for it might in soine instance lead to the conclusion that houses are separate property, and thus not available for the use of minor children. However, this argument applies with equal force to all family residences, while the family residence presumption applies only to single family residences held in joint tenancy. Thus, this argument proves too much, because it is generally contrary to the community property system as adopted in California.

70. See supra note 13.

71. E.g., Gudelj v. Gudelj, 41 Cal. 2d 202, 212, 259 P.2d 656, 662 (1953); Socol v. King, 36 Cal. 2d 342, 346, 223 P.2d 627, 630 (1950); Machado v. Machado, 58 Cal. 2d 501, 506, 375 P.2d 55, 58, 25 Cal. Rptr. 87, 90 (1962).

72. Siberell v. Siberell, 214 Cal. 767, 771-73, 7 P.2d 1003, 1005 (1932).

73. Machado, 58 Cal. 2d at 506, 375 P.2d at 58, 25 Cal. Rptr. at 90; see also Gudelj, 41 Cal. 2d at 212, 259 P.2d at 662; Socol, 36 Cal. 2d at 346, 223 P.2d at 630 .

74. E.g., Whittaker v. Whittaker, 137 Cal. App. 396, 399, 30 P.2d 538, 539 (3d Dist. 1934) (married woman presumption). 
marriage. The very purpose of the family residence presumption is to give no legal effect to the joint tenancy deed and instead to presume that the property is community property. Thus, it is illogical to look to the joint tenancy title presumption in determining the effect of tracing on property presumed to be community property by operation of the law. Rather, one should look to the community property doctrine holding that tracing is the method by which to classify the property. ${ }^{75}$

Third, when the legislature amended section 5110 to include the family residence presumption, it was undoubtedly aware that the court generally allowed tracing to overcoine the other presunuptions in the statute. ${ }^{76}$ Therefore, it probably intended that the new language be interpreted in the same manner. This conclusion is explicitly supported by the legislative history of the family residence presumption:

The proposal would not preclude a husband and wife from actually holding property as joint tenants. It would merely impose upon them the burden of overcoming the contrary proposition. This saine burden is presently on thein in reverse in that they must overcome the presumption the property has been changed from commumity property to jomt tenancy. In either event, proof to overcome the presumption would be by tracing the funds which were used to make the purchase or showing an agreement between the parties. ${ }^{77}$

Thus, legislative history and proper statutory construction support the position that the family residence presuniption can be overcoune by tracing.

\section{Policy Arguments Against the Lucas Gift Presumption}

This Subsection argues that a gift presumption in the Lucas situation $^{78}$ cannot be justified on policy grounds: first, because no gift is usually intended in the Lucas type of situation; second, because the reasons favoring a gift presumption in this situation became obsolete in

75. See De Funiak \& Vaughn, supra note 36.

76. See Malcolm v. Superior Court, 29 Cal. 3d 518, 528, 629 P.2d 495, 500, 174 Cal. Rptr. 694, 699 (1981); Enyeart v. Board of Supervisors, 66 Cal. 2d 728, 735, 427 P.2d 509, 513, 58 Cal. Rptr. 733, 737 (1967) ("The legislature is presumed to know of existing domestic judicial decisions and to have thein in mind wheu amending statutes which the courts have construed."); 2A C.D. SAND, supra note $68, \S 22.35$ (4th ed. 1972).

77. Domestic Relations Report, supra note 60, at 124 (einphasis added).

78. There are certainly other situations where it may still be desirable for policy reasons to have such a presuinption. One situation would be where funds were not available for repayunent, such as where property had not been purchased with the funds. The "family expense" presuinption, see infra note 86 and accompanying text, could be an example of that; one would not want a debt from the community to one spouse's separate estate to build up so that as a result of the property division, one spouse had a net debt to the other. However, there are more direct ways of avoiding such a result. For instance, there is a duty of support, see CAL. CIv. CoDE $\$ 5100$ (West 1970 ), that can be relied upon instead of a presumption of a gift to justify a refusal to return separate inouies spent on cominumity expenses. 
1975 with the adoption of co-management of community property; and third, because a gift presumption, which hinges the disposition of any particular case upon the existence or nonexistence of a parol agreement made in the distant past, is im general unworkable.

\section{a. No Intention of Gift}

A presumption that a down paynient fron separate funds during marriage is a gift can be defended on the ground that $m$ inany cases the spouse actually intends to make a gift, and only repudiates it later when the marriage sours.

It is conceded that many spouses may have an mtent to make a gift in such situations. Moreover, the gift may at least arguably meet the legal requirements of dehvery. Simce both spouses retaim an interest in community property, exclusive use by the recipient could not be required to establish dehvery. Thus, the legal requirements for "delivery" to the community might be accomplished merely by one spouse allowing the other to use the disputed article.

The most realistic view of the situation, however, is that the parties had no imtentions whatsoever regarding the disposition of the property upon divorce. In all probability, neither thouglit about disposition upon divorce, nor did they discuss it, nor did they understand the legal implications of various ways of holding title (other than perhaps that jomt tenancy would allow one to avoid probate). Marriages are not usually made in contemplation of divorce.

A more accurate presumption would be that gifts made during marriage are based on an underlymg presumption of continumg marriage, and so should be conditional upon the contmuation of the marriage. This view has been adopted in Louisiana and several foreign countries. ${ }^{79}$ Moreover, even in American jurisdictions the notion of conditional gifts is not uncommon; ${ }^{80}$ it is well settled that a gift made im contemplation of death is revoked if the donor survives his peril. ${ }^{81}$ The contrary presumption that a spouse made an unconditional gift in spite of possible divorce is not convincing.

79. Fuller v. Ferguson, $26 \mathrm{Cal}$. 546, 573-74 (1864) (gifts between spouses revocable under Mexican community property law); LA. Civ. CODE ANN. art. 156 (West 1952) (upon divorce, spouse loses "donations" [gifts] made by other spouse). See also CoDE Civil arts. 267-269 (Fr. 1968), translated in J. CRABB, The French Civil Code 68-69 (1977); Marriage Code § 73 (W. Ger. 1946), translated in INTROdUCtORY ACT TO THE GERMAN CIVIL CODE AND MARRIAGE LAW of THE FEDERAL Republic OF Germany 52 (S. Goren trans. 1976); F. LAWSON, A. ANTON \& L. Brown, Amos and Walton's introduction to French Law 70 (3d ed. 1967); 1 Planiol, TRAIte Elementaire de Droit Civil nos. 1267-1332 (La. State L. Inst. trans. 1959).

80. See 24 AM. JUR. 2D Husband and Wife \&93 \& nn.10-11 (1966).

81. CAL. CIV. CoDE $\$ 1149$ (West 1954); but see id. $\$ 1148$ (other gifts not revocable). 


\section{b. The Change to Co-Management}

The second policy justification for a presumption that a separate property down payment is a gift to the community is the prevention of prejudice to the wife. Before 1975, a California husband had sole management power over the community property ${ }^{82}$ and the community mode of living. ${ }^{83}$ Because of this, any transaction involving the husband and affecting community expenses and assets was scrutinized carefully to make sure he did not take advantage of his wife. ${ }^{84}$ For example, any diversion of community funds to benefit his separate property was subject to a community claim of reimbursement. ${ }^{85}$ Furthermore, the husband had no right of reimbursement in situations in which he used his separate property to allow the family to live at a higher standard of hiving than would be possible on community funds. ${ }^{86}$ On the other hand, if the liusband expended community or his separate funds to improve the wife's separate property, there was no right of reimbursement front the wife, because it was the husband authorizing the expenditure. ${ }^{87}$

After 1975, however, the legal basis of the husband's superior management power over community property disappeared, and was replaced by co-management by husband and wife. ${ }^{88}$ Although as a matter of social reality many families niay contmue to be dominated by the husband, gender-based rules presuming a gift from separate to commumity property (or vice versa) can no longer be justified by poimting to mequities in the law. At the very least, the current state of the law demands uniformity. If the Lucas gift presumption is to stand, then community funds spent to improve separate property sliould be considered either gifts from the community or loans which later must be repaid, regardless of whether it was the husband's or the wife's property that received the improvement.

Given the change to co-management, the better rule is to presunie

82. Id. $\S \S 5125,5127$ (West 1970) (amended 1973; effective date Jan. 1, 1975).

83. Id. $\S 5101$ ("The husband is the head of the family. He may choose any reasonable place or mode of hiving, and the wife inust conform thereto.") (repeal enacted in 1973; effective date Jan. 1, 1975).

84. Cf. Schindler v. Schindler, 126 Cal. App. 2d 597, 603, 272 P.2d 566, 269 (2d Dist. 1954) (no gift; restriction on husband's control of community property strictly for benefit of wife); In re Estate of McNutt, 36 Cal. App. 2d 542, 552, 98 P.2d 253, 258 (2d Dist. 1940).

85. Dunn v. Mullan, 211 Cal. 583, 296 P. 604 (1931); In re Marriage of Warren, 28 Cal. App. 3d 777, 782-83, 104 Cal. Rptr. 860, 863-64 (2d Dist. 1972).

86. See v. See, 64 Cal. 2d 778, 785, 415 P.2d 776, 781, 51 Cal. Rptr. 888, 893 (1966); see In re Marriage of Epstem, 24 Cal. 3d 76, 83 n.1, 592 P.2d 1165, 1169 n.1, 154 Cal. Rptr. 413, 417 n.1 (1979) (a husband should not, by his unilateral power to select the mode of living, be able to create a debt of the community in his favor, thus "burdening" the community assets).

87. Shaw v. Bernal, 163 Cal. 262, 124 P. 1012 (1912).

88. See supra note 63 . 
that no gift was made. If a transaction is incorrectly treated as if no gift had been made, then the receiving party has at most lost an expectation of gain by gift. ${ }^{89}$ On the other hand, if a transaction is incorrectly treated as a gift, then the alleged donor will have actually lost money or property of which the alleged donor had undisputed ownership before the inarriage. Thus, there will be greater unfairness to an alleged donor if a gift presumption is incorrect than there will be to an alleged recipient if a non-gift presumption is incorrect. This potential for greater unfairness is enhanced because of the difficulty inherent in proving the nonexistence of a gift between people who presumably spend a substantial amount of time together out of the presence of witnesses. ${ }^{90}$ Thus, a realistic assessment of possible prejudice to all parties no longer supports a presumption of gift between the parties and the community.

\section{c. The Difficulties of Administration}

Apart from the argunient that the presuinption concerning the down payment is unfair, presumptions based on the assumed motivation of a party are generally bad rules of law. They are institutionally difficult to administer, they open the door to perjury and fraud, and they assume a conscious motivation where often there is none.

Institutionally, a gift presumption gives the courts the difficult task of deciding what evidence will establish an "understanding" sufficient to overcoine the presumption of a gift.91 Requiring proof of an express oral or written agreenient for each piece of property works an injustice against a party who always assumed that his or her separate property would remain separate, but neglected to make such an agreement for each specific piece. On the other hand, evidence of the parties' course of conduct regarding the property is bound to be ambiguous; use of property by both spouses is neither conclusive of nor irreconcilably inconsistent with a gift.

The risk of perjury and fraud is substantial for several reasons. First, the stakes can be very high; the disposition of a down payment of many thousands of dollars could depend upon proving an oral agree-

89. The alleged recipient may argue that he gave up the opportunity to buy a separate property house in rebance on the alleged gift. Part III of this Comment presents a method to apportion the house which compensates sucls a person for the lost opportunity resulting from such reliance. See infra text accompanying notes 118-22.

90. The law tends to disfavor finding gifts. Accordingly, as a general rule, gifts must be established by clear and convincing evidence, see, e.g., 35 CAL. JUR. 3D Gifts \& 47, at 374 \& n.28 (1977), and there is no general presumption of a gift. Denigan v. Hibernia Sav. \& Loan Soc'y, 127 Cal. 137, 141, 59 P. 389, 390 (1899).

91. See Comment, Form of Title Presumptions in California Community Property Law: The Test for a "Common Understanding or Agreement," 15 U.C.D. L. REv. 95 (1981). 
ment $t^{92}$ many years after its making. Furthermore, there will be a paucity of impartial witnesses. Disinterested third parties are not likely to be present when such agreements are inade. When the agreement's existence is formally contested, the spouses theinselves are likely to be angry and upset, not the best of circumstances under which to determine the existence of an unverified agreement.

Finally, as noted previously, it is unrealistic to assume that an agreement will exist at all. Most marriages are not planned im contemplation of divorce. However convenient it might be for the legal systen to require written agreelnents of this sort, it seems unrealistic to ask people to make them.

\section{III}

\section{Division of the FAMILY ReSIDENCE}

Probably the most complex task the California Suprene Court faced in Lucas and Moore was that of determining the proper division of the family residence between the spouses. The principal issue was how to allocate the significant appreciation the house had realized during the marriage. ${ }^{93}$ Section $\mathrm{A}$ of this Part analyzes several suggested methods for dividing the family residence appreciation upon marital dissolution. It argues that the primcipal and interest metliod adopted by the Lucas and Moore courts is flawed, although the alternatives previously used by the court of appeal were no better. Section $B$ then proposes a new method for dividing the family residence, a nethod that retains the simplicity of the Lucas/Moore approach and that has the further advantage of being less susceptible to manipulation by the planning of the parties.

\section{A. Analysis of Previous Methods}

\section{Equitable Division}

One suggested method for dividing the family residence is to nrandate an "equitable" allocation of the community and separate property, rather than the strictly equal division of community property required

92. 7 B. WitkIN, supra note 59, Community Property $\$ 73$.

93. Although the Moore court was faced with a case in which a mortgage loan had been taken out prior to marriage, it apparently was not provided with enough information to separate the appreciation on the residence into premarital and postmarital appreciation. In a later appellate court case, In re Marriage of Marsden, 130 Cal. App. 3d 426, 181 Cal. Rptr. 910 (1st Dist. 1982), the court was provided with that information. Interpreting Lucas and Moore, it held that the premarital appreciation was entirely separate property. Because the community could have acquired no interest in the property prior to the marriage absent some type of gift presumption, this conclusion seems necessarily to follow from the definition of separate property. Hence, a party should be entitled to a separate interest in any premarital appreciation of the residence upon proof of the amount of that appreciation. 
by section 4800 of the California Civil Code. ${ }^{94}$ This approach is used in several other community property states. ${ }^{95}$ There are many different sorts of fornulas that could be applied in such a situation, several of which are considered in this Section. The central characteristic of this method is that the judge decides which fornula to use on a case-bycase basis.

The equitable approach is not desirable because of the amount of discretion it gives to the trial judge. Under the equitable inethod, similar cases are likely to be treated differently. For example, a particular formula may be selected in a particular case because a result-oriented judge wishes to rule in favor of a particular hitigant whom the judge feels has been unfairly treated by the other spouse. However, one of the reasons for adopting the strict division required by section 4800 was as part of a schenie for "no-fault" divorce, under which there is no determination of which spouse caused the breakdown, and no pumishment (in the form of an unequal allocation of the community property) for that spouse. ${ }^{96}$ A substantial increase in the trial judge's discretion might undermine this no-fault scheme. If a fair fornula for dividing the residence can be found, it is better to require that formula to be applied uniformly than to leave the matter to the discretion of the court.

\section{Allocation of Appreciation to the Community in All Circumstances}

Another approach, suggested by several commentators, ${ }^{97}$ allocates to the community all of the postinarital appreciation of the property. This method has the obvious advantage of requiring only one simple calculation. It is not entirely clear, lowever, that such a scheme would be permissible under the definition of separate property included in the California Constitution. ${ }^{98}$ For instance, under such a scheme a house

94. Cal. Civ. Code $\S 4800$ (West Supp. 1982).

95. E.g., TeX. FAM. Code ANN. $\$ 3.63$ (Vernon Supp. 1981).

96. In re Marriage of McKim, 6 Cal. 3d 673, 678 \& n.5, 493 P.2d 868, 871 \& n.5, 100 Cal. Rptr. 140, 143 \& n.5 (1972); 33 CAL. JuR. 3D Family Law § 584 (1977).

97. Bruch, supra note 51; Comment, What's Yours is Mine and What's Mine is Mine: The Classification of the Home Upon Dissolution, 28 U.C.L.A. L. REv. 1365, 1386-88 (1981). Neither commentator discusses post-separation, pretrial appreciation. Presumably, it would continue to be.community until division.

98. CAL. Const. art. I, $\S 21$. One commentator argues that such a change would be permitted because of the "mtent to adopt a system with flexible contours." Bruch, supra note 51, at 795 n.104. However, while other community property jurisdictions allocate income from separate property to the community, see id. at $795 \mathrm{n} .103$, no American system based on the French or Spanish models allocates capital appreciation to anyone other than the owner of the separate property. See id. at 796 n.106. Arizona, California, New Mexico, Nevada, and Washington allocate income and capital appreciation to the owner of the separate property. See W. DE FUNIAK \& M. VAughN, supra note 34, at 169-70 \& n.41. Texas, Louisiana, and Idaho allocate separate income to the community, but even those states allocate capital appreciation to the owner of the 
bought solely with separate funds, before marriage, could upon dissolution be partly community property and partly separate property even if no community funds had been spent on it. ${ }^{99}$ It is conceded that the possible unconstitutionality of this method is not an insurmountable obstacle to its adoption, because amendments to the California Constitution are not as uncommon as are anrendments to the federal Constitution. ${ }^{100}$ Amending the constitution is a drastic remedy for the problems involved in the division of the house, however, and Section B discusses a better division method that is easier to effectuate.

\section{Strict Estimation of Costs and Benefits Enjoyed by the Parties}

Another possible method of division would be a strict accounting of who paid for the house, and who received the benefits of homeownership. However, sophisticated accounting of the costs and benefits of homeownership is difficult. First, as the Moore court noted, if the court had considered any costs other than primcipal payınents in determining the parties' respective imterests $i m$ the residence, it would in fairness have to charge the community for the fair rental value of the premises. ${ }^{101}$ In calculating the costs, it would also have to include maintenance expenses as well as fire and casualty insurance. ${ }^{102}$ Furthermore, it would have to classify expenses as capital or non-capital. ${ }^{103}$ Finally, it would have to allow an offset for income tax benefits arising from deductions for property tax and interest paynients. ${ }^{104}$

If all of those items were considered, trial courts would have to

separate property. Id. at 170-71. Thus, it seems that this modification would be more than changing the "flexible contours."

99. If the general rate of inflation is the only reason for the house's appreciation, so that the price of the house relative to other goods in the economy remained unchanged, the appreciation allocated to the community does not flow from any real (i.e., inflation-adjusted) increase in wealth. There is no real increase in wealth, but only an increase in nominal dollar price. Thus, if the community gains an imterest in the property solely as a result of the general rate of inflation, it is arguable that this is not merely a redefinition of separate property, but a plan for the gradual elimimation of separate property as the marriage progresses. If so, it would seem difficult to square with the current constitutional scheine.

100. E.g., Is the Referendum Process Out of Hand?, San Francisco Chron., Feb. 20, 1982, at $28, \mathrm{col} 2$.

101. $28 \mathrm{Cal} .3 \mathrm{~d}$ at $372-73,618$ P.2d at $211,168 \mathrm{Cal}$. Rptr. at 665 .

102. In some jurisdictions, courts also consider factors such as the age and physical condition of the parties, relative need for future support, relative fault in causing the marriage to break up, and the relative income-earning abilities of the parties. See, e.g., Ruprecht v. Ruprecht, 255 Minn. 80, 90, 96 N.W.2d 14, 19 (1959); Fuqua v. Fuqua, 541 S.W.2d 228, 230 (Tex. Ct. Civ. App. 1976).

103. Capital costs, such as improvements, would be properly charged against the equity interest. Non-capital costs, such as maintenance, would be properly charged against the non-equity interest. Anything that raises the value of the house and is only recoverable over a long period is arguably a capital cost, but classification of particular expenses is not always easy.

104. Wetzel v. Wetzel, 35 Wis. $2 d$ 103, 107-09, 150 N.W.2d 484, 485-86 (1967). See I.R.C. $\S 163$ (1976); Cal. Rev. \& TAX. CoDE $\S 17203$ (West Supp. 1982). 
consider evidence froin all the parties regarding taxes, maintenance, insurance, and all other expenses incident to hoineownership. Moreover, in all likelihood there would be conflicting evidence from appraisers about the fair rental value of the house. The benefits in accuracy gained by finetuning the division of the residence thus may be illusory ${ }^{105}$ and not worth the costs of such a sophisticated computation. Perhaps for this reason, courts have adopted formulas based on variables of interest and primcipal paynents, iteins which can be easily verified and are not usually subject to dispute.

\section{Methods Based on Principal/Interest Calculations}

Three methods for allocating the community and separate portions of a residence according to the relative primcipal and interest payments of the spouses were proposed to the Lucas and Moore courts. This Subsection will analyze the three methods, including the approach adopted by the California Supreme Court.

\section{a. Vieux}

The first method is based upon Vieux $\nu$. Vieux. ${ }^{106}$ Under this approach, the total equity in the residence is spht between the community and separate property interests in proportion to the relative share of the total down payment and monthly payments made by each. The distinguishing characteristic of the Vieux method is that, in addition to the down payinent and the monthly principal payment, the interest portion of the loan payinent is also included in the coinputation. ${ }^{107}$

The Vieux rule is unsatisfactory because it is potentially unfair to the party making the down payinent. That party is inaking a contribution directly from his or her assets, and is not encumbering the property with a loan. However, the share of the party making the down payment will be directly influenced by interest payments on the house purchase loan. The interest payments will be determined in part by the interest rate on the loan. The higher the interest rate on the loan, the higher the inonthly loan payinents, and the further the share of the

105. See An Economic Model of the Lucas and Moore Situation (Aug. 20, 1982) (unpublished computer program on file with the California Law Review).

Small differences in variables can radically change the allocation scheme using a sophisticated model. For instance, if one changes the assumption of rental cost as a percentage of housing price from $5 \%$ to $6 \%$, the final allocation of resources can vary by as much as $10 \%$.

106. 80 Cal. App. 222, 229, 251 P. 640, 643 (2d Dist. 1926). See Petition for Hearing at 1-3, Moore (citing Vieux). The Vieux case concerned investment property, not the family residence, and the case does not seem to say what the defendant's petition seems to say it does. Nevertheless, his proposal is reasonable, and will be analyzed here.

107. Vieux, 80 Cal. App. at 229, 251 P. at 643; see Moore, 28 Cal. $3 \mathrm{~d}$ at 371, 618 P.2d at 210, 168 Cal. Rptr. at 664. 
party making the down payment will decline with each loan payment. Thus, under the Vieux method, the borrower has less of an incentive to seek a low interest rate, because any increase im the amount of interest paid is in part offset by the higher portion of the appreciation the borrower will receive. The Vieux method cushions a borrower who negotiates a loan at a high interest rate, at the expense of the spouse who made the down payment.

\section{b. Jafeman}

A second method for dividing the residence was suggested by $I n$ re Marriage of Jafeman. ${ }^{108}$ Under the Jafeman approach, the separate and community interests are first reimbursed for their principal payments. Next, appreciation of the residence is allocated to the separate and community interests in proportion to their relative share of the total principal paid. Only the down payment and the monthly principal payments are considered; the loan balance and other factors are not counted.

Jafeman overcoinpensates the spouse inaking the down payinent if the house is divided shortly after purchase. This is because in that period only a small percentage of the monthly payment is principal; the rest is an interest payment. ${ }^{109}$ Thus, an amount of inoney contributed by way of the first few payments would be inainly interest and would result in a far sinaller return upon dissolution than an equal annount of money spent on the down payment which is entirely a principal payment. Under the Jafeman method, if the parties believe that the inarriage might dissolve within ten or twenty years of the house purchase, it would be to the advantage of each of the parties to try and pay as inuch of the down payment as possible, and attempt to inake the other party pay the monthly payments, even if as a practical matter either party is capable of contributing the down payment. ${ }^{110}$

\section{c. Lucas/Moore}

The third approach, origmating in In re Marriage of Aufmuth, ${ }^{111}$ was adopted by the court in Lucas and Moore. ${ }^{112}$ Under this approach, as in the Jafeman method, each party is reimbursed for its principal payments. However, the principal payments are not the only factor taken into consideration in allocating the house appreciation. Unlike

108. 29 Cal. App. 3d 244, 256-57, 105 Cal. Rptr. 483, $491-92$ (1st Dist. 1972).

109. For example, on a conventional 30 -year mortgage with a $10 \%$ interest rate, approximately $0.53 \%$ of the first year's payinents will be credited toward principal.

110. $28 \mathrm{Cal}$. 3d at 372,618 P.2d at $211,168 \mathrm{Cal}$. Rptr. at 665 .

111. 89 Cal. App. 3d 446, 454-57, 152 Cal. Rptr. 668, 673-75 (1st Dist. 1979).

112. Lucas, 27 Cal. 3d at 816, 614 P.2d at 289-90, 166 Cal. Rptr. at 858; Moore, 28 Cal. 3d at 373,618 P.2d at $211,168 \mathrm{Cal}$. Rptr. at 665. 
Jafeman, under Lucas/Moore the party who contributed the loan proceeds is credited with the share of the appreciation attributable to the loaned funds not repaid by the time of separation.

Crediting the party who contributed the loan proceeds with a pro rata share of the appreciation, as under Lucas/Moore, has the advantage of making the down payment a sort of purchase as a cotenant, coinpletely insulated from any financing scheme the other party may use. A twenty percent down payment would entitle the party making the down payment to a twenty percent interest in the house by virtue of that payinent, notwithstanding varying interest or principal payments by the other party. At least in the situation where the loan is paid by the saine party who takes it out, the length of the marriage does not affect the proportion of the appreciation paid to each party, although the longer the marriage, the more appreciation there presumably is.

The Lucas/Moore method is defective, however, as apphied to loans which are taken out by one party before marriage and paid by the other or by the commumity after marriage. The defect is that, as part of its allocation of the appreciation in proportion to the contributions to the purchase price, Lucas/Moore treats the loan proceeds as an asset that was contributed entirely as separate or community property. ${ }^{113}$ This means that the loan proceeds are misallocated to the extent that principal payments are made by other than the interest taking out the loan.

The determination of whether the loan is a separate or community contribution is made by reference to California law on the classification of assets bought with borrowed inoney-by ascertaming the source the lender looked to for security for the loan. ${ }^{114}$ In general, when preexist-

113. Moore, $28 \mathrm{Cal} .3 \mathrm{~d}$ at 373, 618 P.2d at 211, $168 \mathrm{Cal}$. Rptr. at 665 .

114. Id. (" $[\mathrm{T}]$ he loan was based on separate assets and was therefore a separate property contribution."); see Lucas, 27 Cal. 3d at 816 \& n.3, 614 P.2d at 290 \& n.3, 166 Cal. Rptr. at 858 \& n.3; 7 B. WITKIN, supra note 59, Community Property \$ 31 (8th ed. 1974 \& Supp. 1980); 32 CAL. JUR. 3D Family Law $\$ 415$ (1977).

Categorizing unpaid loan proceeds based on the security used for repayment where the only secnrity (apart from earnimgs) is the property being purchased seems odd at first glance. The Moore court's objection that payments for interest and other past obligations are not "property to be divided by the court" would seem an appropriate characterization of an unpaid loan balance also. Loan proceeds cannot be separated from the loan obligation, and any evaluation of them both together is likely to result in a zero or negative net value due to the profit margin the lender must have. Furthermore, unlike a loan secured by other preexisting separate or cominunity assets, there is an inherent circnlarity in trying to classify an outstanding mortgage balance because the loan is secured by the asset being purchased. Nevertheless, the accepted law seems to be that in general, im order for loan proceeds to be classified as separate property, it inust be shown that the security provided was separate property; otherwise the general presuinption of coinmunity property applies. Gudelj v. Gndelj, 41 Cal. 2d 202, 210, 259 P.2d 656, 661 (1953).

For a comparison of California law regarding the classification of loan proceeds with the law of other community property states, see Young, Community Property Classification of Credil Acquisitions in California: Law without Logic?, 17 CAL. W.L. REv. 173 (1981). In other states, for 
ing separate property is pledged as security for a loan, those loan proceeds are classified as separate property. ${ }^{115}$

Unlike the classification of a loan secured by other preexisting separate or community assets, however, there is an inherent circularity in trying to classify an outstanding mortgage balance, because the loan is secured by the asset being purchased. To resolve this problem, the accepted law is that in order for loan proceeds to be classified as separate property, it must be shown that the security provided was separate property. Otherwise, the general presumption of community property applies. ${ }^{116}$ Therefore, a mortgage loan taken out during marriage is classified as community property except under unusual circumstances, such as a couple living completely from separate imcoine (e.g., mvestments). However, a mortgage taken out before marriage is classified as separate property because the lender must have looked to separate property for security.

Under California law, once the loan proceeds are classified, they are not reclassified upon a subsequent marriage. ${ }^{117}$ Thus, by fixing the classification based on the set of facts at the time the loan was taken out, the scheme puts great weight on when the loan was taken out, and no weight on who made the actual payments. For instance, the great difference between the allocation in Lucas and Moore is that a lender must have looked to Lydie Moore's separate property for security, since she was unmarried at the time she took out the loan, and thus the loan was classified as separate property. This classification stood even though she subsequently married, and the community made the great majority of the payments on the loan. In contrast, im Lucas the loan

example Washington, the test is what source the borrower intended to repay the loan from. See id. at 243-45. However, it is unclear even under this rule whether a subsequent change in the intent of the borrower will result in reclassification of the loan proceeds. Under California law, the classification is fixed at the receipt of the loan, and the pattern of subsequent repayment has no effect on the classification. Id. at 175-76 (citing Ives v. Connacher, 162 Cal. 174, 177, 121 P. 394, 395 (1912)). The distinction could be crucial in a case such as Moore: if Lydie Moore knew she was going to marry and to pay the loan payments out of her (then) community earnings, it appears the loan would be community uuder the Washington rule. However, if she did not contemplate marriage at the time she took out the loan, but afterwards decided to marry and use community funds to pay back the loan, it is unclear how the Washington rule would classify the loan.

Another oddity of the California approach exists because there is no personal liability on purchase inoney mortgages for single-family dwellings. CAL. CIV. Proc. Code $\$ \$ 580 a-c$ (West 1976). Thus, the fact that both spouses sign the loan papers does not mean there is an enforceable personal obligation on either of them. If only one contributed to the down payment, the other has incurred no hability past the amounts he or she actually pays on the loan. Consistent with this rule of no personal liability, the fact that either signs the loan is not sufficient evidence to hold that the signatory "owns" the loan proceeds or anything bought with it. See Hicks v. Hicks, 211 Cal. App. 2d 144, 153-54, 27 Cal. Rptr. 307, 313 (4th Dist. 1962).

115. E.g., Heney v. Pesoli, 109 Cal. 53, 63, 41 P. 819, 822 (1895).

116. Gudelj v. Gudelj, 41 Cal. 2d 202, 210, 259 P.2d 656, 661 (1953).

117. Ives v. Connaclier, $162 \mathrm{Cal} .174,177,121$ P. 394, 395 (1912). 
was taken out during marriage, and so it was classified as community property. No persuasive reason exists for this disparity.

\section{d. Summary}

Each principal and interest method used so far may be described as a fraction. The Vieux fraction has as the numerator the amount of money (including down payment, principal; and interest payment) each party contributed in order to purchase the house, and as the denominator the total amount of money contributed. The Vieux fraction is applied to the total equity in the house.

The Jafeman fraction has as the numerator the amount of principal (includimg down payment) each party paid, and as the denouninator the total amount of such principal paid. The Lucas/Moore fraction has as the numerator the amount of principal each party paid (including the down payment), plus each party's allocated share of the unpaid loan balance. The denommator is the original purchase price of the residence. Under both Jafeman and Lucas/Moore, the principal paid into the house is returned to the parties, and the fractions are applied to the appreciation of the house.

\section{B. The Proposed Solution}

To correct the misallocation of the loan proceeds under the Lucas/ Moore formula, this Comment proposes ${ }^{18}$ a modification of the method by which the loan balance is allocated. This modification is more sensitive to the relative amounts each party pays on the loan, but is less susceptible to mampulation.

The proposed method is to allocate the appreciation attributable to the loan proceeds to separate or community sources pro rata according to the total number of monthly payments made froin separate or coinmumity sources between the time the loan is taken out and the time the parties separate. ${ }^{119}$ In order to prevent a party from manipulating the results of the formula by prepaying part or all of the loan, perhaps just before a marital separation, any additional principal paid apart from the normal monthly payments is not considered when allocating the appreciation. All paynients of principal, including payments in excess

118. This proposed method is similar to one outlined in Comment, Apportionnent of Home Equity in Marital Dissolutions Under California Community Property Law: Is the Current Approach Equitable?, 9 Community Prop. J. 31 (1982). However, that Comment did not address inany of the issues considered here (for example, premarital and postmarital appreciation, and possibility of manipulation).

119. Thus, if the husband made 20 payinents on the loan and the community made 100 , and the loan balance at the time of separation was $\$ 50,000$, then the husband would be allocated 20 / $120 \times \$ 50,000=\$ 8,333$ of the unpaid loan balance, and the community $100 / 120 \times \$ 50,000=$ $\$ 41,667$. 
of the regular monthly amounts and any payments made after the parties separate, are returned to the party making them, but the appreciation attributable to those extra payments is not allocated to that party. ${ }^{120}$

The appreciation is shared according to the number of monthly payments, and not the amount of monthly principal payments, both for reasons of simphicity and fairness. Adding the varying principal payinents is more complicated, but the more important objection is that it gives a windfall to the party making the later payments, because the principal portion of the monthly paynent rises over the term of a fully amortized level payment loan. Counting only the number of payments avoids affecting the shares because of the timing factor.

There are two main differences between the proposed method and the Lucas/Moore formula. First, Lucas/Moore allocates all of the loan balance share to the separate or community property interest that secured the loan while the proposed method allocates the loan balance share pro rata based on the proportionate contribution of principal payments by the two interests. Second, the two methods differ in their treatment of loan payments made in addition to the regular monthly amount. Under Lucas/Moore, if a spouse pays off the loan completely rather than inaking the norinal monthly payinents, the spouse could radically change the allocation of the house in his or her favor. In contrast, while the proposed method would return the separate property payment inade for such a purpose, the percent allocation of appreciation would be the same as if the loan had been paid in nornal monthly installments.

The proposed formula is superior to the unmodified Lucas/Moore fornula because the party considered to "own" the loan for the purposes of the property division is determined solely by the pattern of repayinent during inarriage. Allowing events subsequent to the borrowing to influence the allocation scheine is desirable for several reasons. First, the lender's intended security provides a unrehable measure of who is in fact assuming the loan obligations. For instance, if in Moore the loan was made on the basis of future income, that income was separate at the time the loan was made. When Lydie Moore married, however, the incoine froin that point on became community; yet under the Lucas/Moore scheme the loan proceeds were not reclassified. Second, the evidentiary requirements under the proposed forinula

120. Thus, in the example in note 119 , if the husband made 15 more payments after separation, he would receive back the principal amounts he paid in those 15 payments, but the payments would not enter into the calculation of the unpaid loan balance to be attributed to the parties. In addition, the loan balance in question is the Ioan balance as of separation, rather than as of the date of property division, as it is under the unmodified Lucas/Moore rule. 
are less than under the Lucas/Moore formula because there is no need to inquire imto the lender's intent. ${ }^{121}$ Third, the proposed method prevents events of less actual econoinic significance, such as the relative order of marriage and purchase, from having any effect on the allocation scheme. ${ }^{122}$ Finally, the calculation is very similar to that under Lucas/Moore and thus preserves the relative simplicity of that approach.

\section{CONCLUSION}

This Comment makes two suggestions for improving the division of the family residence upon marital dissolution under the Lucas/ Moore scheine. First, no agreement should be required to establish the separate property character of a down payment made from separate funds during inarriage. The Lucas gift presumption should be eliminated. Second, where the house loan payments are made from both separate and community sources, such as before and during marriage, the proceeds of the loan should be allocated in the ratio of the amount of payments made from each source.

Each of these suggestions is a relatively simple modification to the method of division established in Lucas and Moore, but each will substantially mcrease the fairness of the apportionment witlout adding any burdensome proof or calculation requireinents. Although a more accurate estimation of the benefits received by each interest can be atteinpted, practical considerations weigh heavily against the increase in accuracy that in theory could result.

Peter M. Moldave*

121. As noted earlier, see supra text accompanying note 105, proof of actual amounts paid on the loan is probably the most reliable and available evidence possible, since it is available from bank or finance company records, and in the ordinary case would not be subject to serious dispute. Proof of a lender's intent would require the testinony of the loan officer, or the admission of the files of the lending imstitution. For a survey of what kind of testimony would be expected from lenders, see Young, supra note 114, at 251-54.

122. The order of marriage and purchase may be correlated with events which influence the division scheme, such as payinents on the loan and the premarital appreciation of the property. Unlike payinents and appreciation, however, which have an effect on the allocation scheme in rough correlation to the length of the inarriage, the allocation of the unpaid loan balance has an effect inversely correlated with the length of the inarriage. As the marriage grows longer, the unpaid loan proceeds shrink, and their allocation becomes of less importance. When the loan is coinpletely paid off, the Jafeman, Lucas/Moore, and proposed schemes all allocate the property in the same manner, apart from calculations of premarital and postmarital appreciation.

* A.B. 1980, Harvard College; third-year student, Boalt Hall School of Law, University of California, Berkeley. 